\title{
PENGARUH SISTEM AKUNTANSI PEMERINTAH DAN SISTEM PELAPORAN TERHADAP AKUNTABILITAS KINERJA INSTANSI PEMERINTAH KOTA BENGKULU
}

\author{
Rina Yuniarti \\ Fakultas Ekonomi Universitas Muhammadiyah Bengkulu
}

\begin{abstract}
ABSTRAK
Rina Yuniarti; Berdasarkan Peraturan Pemerintah No. 24 Tahun 2005 tentang Standar Akuntansi Pemerintahan (SAP). Standar Akuntansi Pemerintahan adalah prinsip-prinsip akuntansi yang diterapkan dalam menyusun dan menyajikan laporan keuangan pemerintah. Dengan demikian, Standar Akuntansi Pemerintahan merupakan persyaratan yang mempunyai kekuatan hukum dalam upaya meningkatkan kualitas laporan keuangan instansi pemerintah. sistem pelaporan yang baik diperlukan agar dapat memantau dan mengendalikan kinerja manajer dalam mengimplementasikan anggaran yang telah diterapkan.Penelitian ini bertujuan untuk mengetahui pengaruh sistem akuntansi pemerintah dan sistem pelaporan terhadap akuntabilitas kinerja. Sampel penelitian SKPD yang ada di pemerintah kota Bengkulu. Teknik analisa data yang digunakan adalah regresi berganda.Hasil penelitian ini menunjukkan bahwa sistem akuntansi pemerintah berpengaruh terhadap akuntabilitas kinerja dan sistem pelaporan berpengaruh dan terhadap akuntabilitas kinerja
\end{abstract}

\section{ABSTRACT}

Rina Yuniarti; Based on Government Regulation No. 24 Year 2005 regarding the Government Accounting Standards (SAP). Government Accounting Standards are accounting principles applied in preparing and presenting the financial statements of the government. Thus, the Government Accounting Standards are requirements that have the force of law in an effort to improve the quality of financial reports of government agencies. good reporting system is needed in order to monitor and control the performance of managers in implementing budget diterapkan.Penelitian aims to determine the effect of government accounting systems and reporting on performance accountability system. The research sample SKPD in Bengkulu city government. Data analysis technique used is the regression berganda.Hasil this study indicate that the government accounting system affect the performance accountability and reporting systems and the effect on performance accountability

Key words: Government Accounting System, System Reporting, PerformanceAccountability

\section{PENDAHULUAN}

Berdasarkan Peraturan Pemerintah No. 24 Tahun 2005 tentang Standar Akuntansi Pemerintahan (SAP). Standar Akuntansi Pemerintahan adalah prinsip-prinsip akuntansi yang diterapkan dalam menyusun dan menyajikan laporan keuangan pemerintah. Dengan demikian, Standar Akuntansi Pemerintahan merupakan persyaratan yang mempunyai kekuatan hukum dalam upaya meningkatkan kualitas laporan keuangan instansi pemerintah.

Menurut Urip Santoso dan Yohanes Joni Pambelum (2008:4) "penyusunan laporan keuangan yang berpedoman pada standar Akuntansi Pemerintahan bermanfaat untuk pemenuhan kebutuhan informasi keuangan secara umum yang lebih berkualitas bagi para pengguna laporan keuangan didalam rangka menilai akuntabilitas dan membuat keputusan ekonomi, sosial dan politik". Pengelolaan keuangan pemerintah baik pemerintah maupun pemerintah daerah harus sesuai dengan Standar Akuntansi Pemeritahan. Hal ini perlu guna 
meningkatkan keterbandingan laporan keuangan baik terhadap anggaran, antar periode, maupun antar entitas. Dengan adanya Standar Akuntansi Pemeritahan dapat mewujudkan pengelolaan keuangan Pemerintah lebih transparans dan accountable.

Pemerintah berkewajiban untuk memberikan informasi keuangan dan informasi lainnya yang akan digunakan untuk pengambilan keputusan ekonomi, sosial, dan politik oleh pihak yang berkepentingan. Lembaga Administrasi Negara (LAN) (2000) mengemukakan, "laporan yang baik adalah laporan yang harus disusun secara jujur, objektif, dan transparan". Laporan umpan balik (feedback) diperlukan untuk mengukur aktivitas-aktivitas yang dilaksanakan dalam rangka meningkatkan kinerja dan akuntabilitas dalam pelaksanaan suatu rencana atau waktu mengimplementasikan suatu anggaran, sehingga manajemen dapat mengetahui hasil dari pelaksanaan rencana atau pencapaian anggaran yang ditetapkan.

Badan Pemeriksaan Keuangan Perwakilan Provinsi Bengkulu telah menuntaskan Pemeriksaan Hasil Pemeriksaan Laporan Keuangan Pemerintah Daerah (LPH LKPD) tahun 2013. Berdasarkan opini BPK RI terhadap Laporan Keuangan Pemerintah Daerah (LKPD) ada 8 entitas yang telah diserahkan dengan rincian empat entitas yang mendapatkan opini WTP yaitu Kabupaten Kaur, Kabupaten Bengkulu Utara, Kabupaten Muko-Muko , dan Kabupaten Bengkulu tengah. Sedangkan Kota Bengkulu, Kabupaten Bengkulu Selatan, Kabupaten Rejang Lebong dan Kabupaten Kepahiang mendapatkan opini WDP. (Bengkulu Ekspress , 13/06/2014)

Pemerintah Daerah Kota Bengkulu mengalami penurunan opini selama 2 tahun dari hasil Pemeriksaan Hasil Laporan Keuangan Pemerintah Daerah (LPH LKPD) oleh BPK RI perwakilan Provinsi Bengkulu, Kota Bengkulu pada tahun Anggaran 2011 memperoleh opini Wajar Tanpa Pengecualian (WTP) sedangkan pada tahun 2012 dan 2013 mendapatkan opini Wajar Dengan Pengecualian(WDP). Penurunan opini pada tahun Anggaran 2012 disebabkan adanya temuan belanja ke sekolah-sekolah di Dinas Pendidikan Nasional Kota Bengkulu yang belum didukung dengan bukti pertanggungjawaban yang memadai, rinciannya senilai Rp. 4,8 Miliar atas Belanja Modal dan Rp.6,5 Miliar atas belanja barang. Dan sejumlah asset yang belum dapat ditelusuri seperti peralatan dan mesin senilai Rp.11,9 Miliar, Gedung dan Bangunan senilai Rp. 36,4 Miliar, serta irigasi senilai Rp. 12 Miliar. Sedangkan pada tahun Anggaran 2013 opini WDP Pemerintah Daerah Kota Bengkulu disebabkan data asset masih belum dapat ditelusuri, Asset tersebut berupa pelaratan mesin (kendaraan roda 4 dan 2) bangunan, luasan tanah yang belum lengkap, dan belanja sebesar Rp.11 miliar. (Bengkulu Ekspress,13/06/2014)

Opini yang diberikan oleh BPK RI atas LKPD bukanlah merupakan hadiah atau pemberian semata. Melainkan adalah mencerminkan kerja keras dan keseriusan dari masingmasing Instansi Pemerintah Daerah, serta mencerminkan akuntanbilitas kinerja pemerintah (AKIP). Penilaian BPK RI berdasarkan dengan pernyataan profesional mengenai kewajaran informasi keuangan yang disajikan masing-masing LKPD. Serta didasarkan pada kriteria kesesuaian dengan standar akuntansi pemerintahan, kecukupan pengungkapan, kepatuhan terhadap hukum perundang-undangan dan efektivitas sistem pengendalian intern Pemerintah.

Dian Tri Hapsari (2014) melakukan penelitian pengaruh penerapan standar akuntansi pemerintahan, ketaatan pada peraturan perundangan, kompetensi aparatur pemerintah daerah dan motivasi kerja terhadap akuntabilitas kinerja instansi pemerintah (Studi Empiris pada Pemerintah Kabupaten Lumajang). diperoleh kesimpulan bahwa penerapan standar akuntansi pemerintahan berpengaruh positif dan signifikan terhadap akuntabilitas kinerja instansi pemerintah.

Penelitian ini merupakan replikasi/modifikasi dari penelitian Tri Hapsari (2014) tentang pengaruh penerapan standar akuntansi pemerintahan, ketaatan pada peraturan perundangan, kompetensi aparatur pemerintah daerah dan motivasi kerja terhadap akuntabilitas kinerja instansi pemerintah (Studi Empiris pada Pemerintah Kabupaten Lumajang. Perbedaan penelitian ini dengan penelitan Tri Hapsari (2014) terletak pada objek penelitian dan variabel penelitian. Objek penelitian Tri Hapsari (2014) adalah instansi pemerintah Kabupaten Lumajang sedangkan penelitian ini menggunakan objek penelitian Instansi Pemerintah Kota Bengkulu pada tahun 2014. Pada penelitian Tri Hapsari (2014) menggunakan penerapan standar akuntansi pemerintahan, ketatatan pada peraturan perundangan, kompetensi aparatur pemerintah daerah dan motivasi kerja terhadap 
akuntabilitas kinerja, sedangkan pada penelitian ini menggunakan variabel standar akuntansi pemerintahan dan sistem pelaporan sebagai variabel independen.

Berdasarkan latar belakang yang telah diuraikan diatas, maka penaliti tertarik melakukan penalitian mengenai : "Pengaruh Standar Akuntansi Pemerintahan dan Sistem Pelaporan Terhadap Akuntabilitas Kinerja Isntansi Pemerintah Daerah Kota Bengkulu”.

\section{Rumusan Masalah}

1. Apakah Standar Akuntansi Pemerintahan secara parsial berpengaruh terhadap Akuntabilitas Kinerja Instansi Pemerintah Daerah Kota Bengkulu?

2. Apakah Sistem Pelaporan secara parsial berpengaruh terhadap Akuntabilitas Kinerja Instansi Pemerintah Daerah Kota Bengkulu?

3. Apakah Standar Akuntansi Pemerintah dan Sistem Pelaporan secara simultan berpengaruh terhadap Akuntabilitas Kinerja Instansi Pemerintah Daerah Kota Bengkulu?

\section{Landasan Teori \\ Pengertian Anggaran}

Menurut Indra Bastian (2010 : 191)“Anggaran merupakan rencana operasi keuangan yang mencakup estimasi pengeluaran yang diusulkan, dan sumber pendapatan yang diharapkan untuk membiayainya dalam periode waktu tertentu."

Mardiasmo (2000:61), mendefinisikan “Anggaran merupakan pernyataan mengenai estimasi kinerja yang hendak dicapai selama periode waktu tertentu yang dinyatakan dalam ukuran finansial, sedangkan penganggaran adalah proses atau metode untuk mempersiapkan suatu anggaran." Dan Abdul Halim (2007:164) mengartikan "Anggaran merupakan sebuah rencana yang disusun dalam bentuk kuantitatif dalam satuan moneter untuk satu periode dan periode anggaran biasanya dalam jangka waktu setahun"

\section{Karakteristik Anggaran}

Menurut Indra Bastian (2010 : 192), karakteristik anggaran publik terdiri dari :

1. Anggaran dinyatakan dalam satuan keuangan dan satuan nonkeuangan.

2. Anggaran yang umumnya mencakup jangka waktu tertentu, yaitu satu atau beberapa tahun.

3. Anggaran yang berisi komitmen atau kesanggupan manajemen untuk mencapai sasaran yang ditetapkan.

4. Usulan anggaran yang ditelah dan disetujui oleh pihak yang berwenang yang lebih tinggi dari penyusunan anggaran.

5. Anggaran yang telah disusun hanya dapat diubah dalam kondisi tertentu.

\section{Fungsi Anggaran}

Fungsi anggaran menurut Indra Bastian (2010 : 191) adalah sebagai berikut:

1. Anggaran merupakan hasil akhir dari proses penyusunan rencana kerja.

2. Anggaran merupakan cetak biru aktivitas yang akan dilaksanakan di masa yang akan datang.

3. Anggaran sebagai alat komunikasi internal yang menghubungkan berbagai unit kerja dan mekanisme kerja antar atasan serta bawahan.

4. Anggaran sebagai alat pengendalian unit kerja.

5. Anggaran sebagai alat motivasi dan persuasi tindakan yang efektif serta efisien dalam pencapaian visi organisasi.

\section{Standar Akuntansi Pemerintahan}

Sesuai dengan amanat Undang-undang Nomor 17 tahun 2003, pemerintah menetapkan Peraturan Pemerintah tentang standar akuntansi pemerintahanan (SAP) yang tertuang dalam Peraturan Pemerintah Nomor 24 Tahun 2005 tentang standar akuntansi pemerintahan. Standar akuntansi pemerintahan adalah prinsip-prinsip akuntansi yang diterapkan dalam menyusunan menyajikan laporan keuangan pemerintah. Dengan demikian, standar akuntansi 
pemerintahan merupakan persyaratan yang mempunyai kekuatan hukum dalam upaya meningkatkan kualitas laporan keuangan pemerintah di Indonesia

Pada tahun 2010 diterbitkan Peraturan Pemerintah No. 71 Tahun 2010 tentang standar akuntansi pemerintahan, sehingga sejak saat itu Peraturan Pemerintah No. 24 Tahun 2005 dinyatakan tidak berlaku lagi. Peraturan Pemerintah No. 71 Tahun 2010 mengatur penyusunan dan penyajian laporan keuangan berbasis akrual. Peraturan Pemerintah Nomor 71 Tahun 2010 Standar akuntansi pemerintahan tercantum dalam dua lampiran Peraturan Pemerintah Nomor 71 Tahun 2010, yaitu: standar akuntansi pemerintahan berbasis akrual dan standar akuntansi pemerintAhan menuju berbasis akrual.

Standar Akuntansi Pemerintahan Berbasis Akrual, yaitu standar akuntansi pemerintahan yang mengakui pendapatan, beban, aset, utang, dan ekuitas dalam pelaporan finansial berbasis akrual, serta mengakui pendapatan, belanja, dan pembiayaan dalam pelaporan pelaksanaan anggaran berdasarkan basis yang ditetapkan dalam APBN/APBD. Standar Akuntansi Pemerintahan berbasis Akrual tersebut dinyatakan dalam bentuk Pernyataan Standar Akuntansi Pemerintahan (PSAP) dan dilengkapi dengan Kerangka Konseptual Akuntansi Pemerintahan.

\section{Sistem Pelaporan}

Menurut Indra Bastian (2010 : 297) "pelaporan kinerja merupakan refleksi kewajiban untuk mempresentasikan dan melaporkan kinerja semua aktivitas serta sumber daya yang harus dipertanggungjawabkan. Pelaporan ini merupakan wujud dari proses akuntabilitas kinerja ". Setiap instansi pemerintah berkewajiban untuk menyiapkan, menyusun, dan melaporkan laporan keuangan secara tertulis, periodik dan melembaga. Laporan keuangan isntansi pemerintah merupakan representasi posisi keuangan dari transaksi-transaksi yang dilakukan oleh instansi pemerintah.

Pelaporan kinerja dimaksudkan untuk mengkomunikasikan capaian kinerja instansi pemerintah dalam suatu tahun anggaran yang dikaitkan dengan proses pencapaian tujuan dan sasaran instansi pemerintah. Pelaporan kinerja oleh instansi pemerintah ini dituangkan dalam dokumen Laporan Akuntabilitas Kinerja Instansi Pemerintah (LAKIP).

Menurut Mardiasmo (2002:162) tujuan umum dari penyampaian laporan keuangan oleh instansi pemerintah adalah :

1. Untuk memberikan informasi yang digunakan dalam pembuatan keputusan ekonomi, sosial, dan politik serta sebagai bukti pertanggungjawaban (accountability) pengelolaan (stewardship).

2. Untuk memberikan informasi yang digunakan untuk mengevaluasi kinerja manajerial da organisasional.

\section{Akuntabilitas Kinerja Instansi Pemerintah}

Menurut Mardiasmo (2009:20) "Akuntabilitas publik merupakan Kewajiban seorang pemeggang amanah untuk memberikan informasi, pertanggungjawaban, menyajikan, melaporkan dan mengungkapan segala aktifitas kegiatan yang menjadi tanggungjawabnya kepada pihak pemberi amanah yang memiliki hak dan kewenangan untuk meminta pertanggungjawaban tersebut"

Abdul Halim (2007 : 20) "Akuntabilitas publik adalah kewajiban-kewajiban dari individu atau penguasa yang dipercayakan untuk mengelola sumber daya publik dan yang bersangkutan dengannya untuk dapat menjawab hal-hal yang menyangkut pertanggungjawaban pegawai pemerintah kepada publik yang menjadi konsumen layanannya"

Keputusan Kepala LAN No.239/IX/6/8/2003 tentang Pedoman Penyusunan Pelaporan Akuntabilitas Kinerja Instansi Pemerintah, menjelaskan bahwa akuntabilitas kinerja instansi pemerintah adalah perwujudan kewajiban suatu instansi pemerintah untuk mempertanggungjawabkan keberhasilan dan kegagalan pelaksanaan misi organisasi dakam 
mencapai sasaran dan tujuan yang telah ditetapkan melalui sistem pertanggungjawaban secara periodik.

Dari uraian diatas, dapat dikatakan bahwa akuntabilitas merupakan perwujudan kewajiban seseorang atau unit organisasi untuk mempertanggungjawabkan pengelolaan dan pengendalian sumber daya serta pelaksanaan kebijakan yang dipercayakan kepadanya dalam rangka mencapai sasaran atau tujuan yang telah ditetapkan dalam dokumen perencanaan melalui media pertanggungjawaban secara periodik.

Mardiasmo (2002 : 21) akuntabilias publik terdiri atas dua macam, yaitu : (1) akuntabilitas vertikal (vertical accountability), dan (2) akuntabilitas horizontal (horizontal accountability). Lembaga Administrasi Negara (LAN) juga seperti yang dikutip BPKP dalam bukunya Akuntabilitas dan Good Governance (2000:24), membedakan akuntabilitas dalam 3 macam yaitu:

\section{Kerangka Analisis}

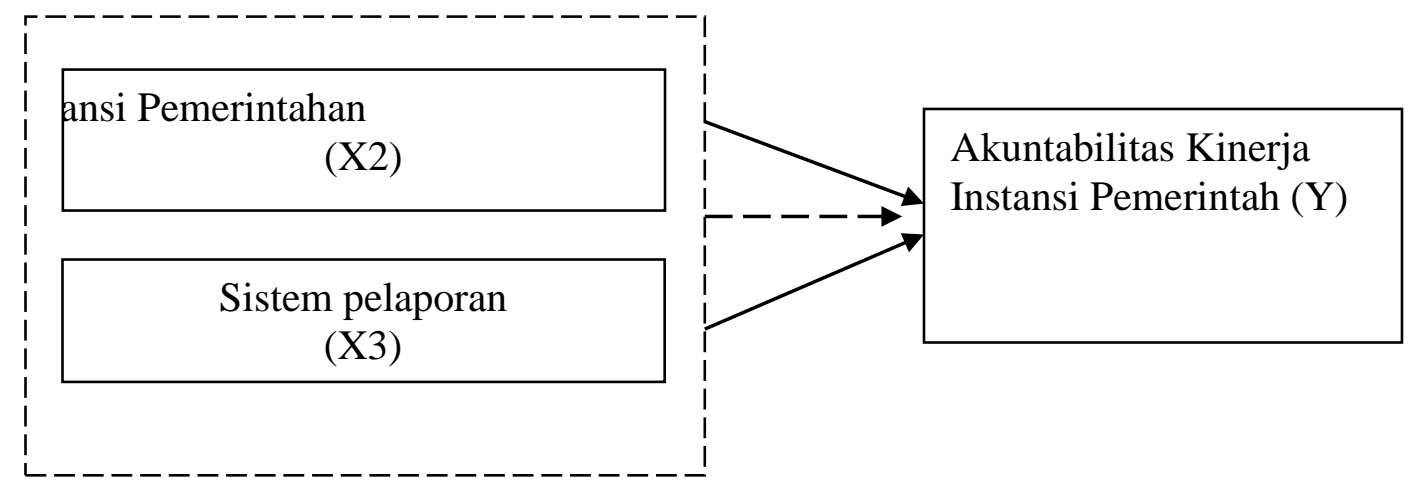

Gambar 1. Kerangka Analisis

\section{Hipotesis}

H1 = Standar akuntansi pemerintahan berpengaruh secara parsial terhadap akuntabilitas kinerja Instansi Pemerintah Daerah Kota Bengkulu.

$\mathrm{H} 2=$ Sistem pelaporan berpengaruh secara parsial terhadap akuntabilitas kinerja Instansi Pemerintah Daerah Kota Bengkulu.

$\mathrm{H} 4$ = Kejelasan sasaran anggaran, standar akuntansi pemerintahan, dan sistem pelaporan berpengaruh secara simultan terhadap akuntabilitas kinerja Instansi Pemerintah Daerah Kota Bengkulu.

\section{HASIL DAN PEMBAHASAN Deskripsi Tingkat Pengembalian Kuisioner}

Populasi dari penelitian ini adalah seluruh pegawai negeri sipil pada SKPD Kota Bengkulu yang berkaitan dengan Tim Anggaran meliputi Pengguna Anggaran (PA), Kuasa Pengguna Anggaran (KPA), Pejabat Pembuat Komitmen (PPK) dan Pejabat Pelaksana Teknis Kegiatan (PPTK) di lingkungan pemerintah Kota Bengkulu. Sesuai dengan metode penarikan sampel yaitu Purposive Sampling responden dalam penelitian ini pegawai negeri sipil yang berkerja di SKPD Kota Bengkulu berkaitan dengan Tim Anggaran meliputi Pengguna Anggaran (PA), Kuasa Pengguna Anggaran (KPA), Pejabat Pembuat Komitmen (PPK) dan Pejabat Pelaksana Teknis Kegiatan (PPTK). Sampel penelitian ini terdiri dari Kepala Bidang, Kepala Subbagian dan Sekretaris dari setiap SKPD yang berjumlah 197 responden. Pengumpulan data dalam penelitian ini dilakukan dengan menyebarkan kuesioner, yang ditujukan kepada 
responden untuk setiap SPKD yang dijadikan tempat penilitian. Peneliti menyerahkan kuesioner dengan di lampirkan Surat Penelitian dan mengambil kembali kuesioaner tersebut sesuai dengan perjanjian pengambilan.

Kuesioner ditujukan pada 33 SKPD di Kota Bengkulu yang dijadikan tempat penelitian. Kuesioner yang di distribusikan kepada responden sebanyak 197 eksemplar. Jumlah kuesioner yang terkumpul yakni 174 dari total 197 kuesioner yang disampaikan jadi responden rate dalam penelitian ini sebesar 88,32\% (174:197). Dari 174 kuesioner yang terkumpul terdapat 16 kuesioner yang tidak dijawab dengan lengkap dan tidak sesuai kriteria. Dengan demikian jumlah Kuesioner yang dapat diolah sebanyak 158 eksemplar kuesioner (80,50\%). Perhitungan tingkat pengambilan kuesioner dapat dilihat pada tabel 1 berikut :

\section{Tabel 1. Tingkat Pengambilan Kuesioner}

\begin{tabular}{|l|l|l|}
\hline \multicolumn{1}{|c|}{ Keterangan } & \multicolumn{1}{c|}{ Jumlah } & \multicolumn{1}{c|}{ Persentase } \\
\hline yang disampaikan & 197 & $100 \%$ \\
\hline yang tidak dikembalikan & 23 & $11,67 \%$ \\
\hline Jumlah kuesiner yang kembali & 174 & $88,32 \%$ \\
\hline yang tidak lengkap & 16 & $8,12 \%$ \\
\hline Iumlah kuesiner yang dapat diolah & 158 & $830,20 \%$ \\
\hline
\end{tabular}

\section{Sumber: Data diolah, 2014}

\section{Uji Kualitas Data \\ Uji Validitas}

Uji validitas digunakan untuk mengukur valid atau tidaknya kuesioner yang digunakan. Teknik yang digunakan untuk melakukan uji validitas adalah coefficient correlation pearson. Data diakatakan valid jika total setiap konstruknya signifikan pada level 0,05 atau 0,01. Uji validitas dapat dilihat pada Tabel 2. berikut ini:

Tabel 2. Hasil Uji Validitas

\begin{tabular}{|l|c|c|c|}
\hline \multicolumn{1}{|c|}{ Variabel } & Pearson Correlation & sig & Keterangan \\
\hline Sistem Akuntansi Pemerintah & $\mathbf{0 , 6 5 1}-\mathbf{0 , 8 2 1}$ & $\mathbf{0 , 0 0 0}$ & Valid \\
\hline Sistem Pelaporan & $\mathbf{0 , 7 8 0 - 0 , 8 2 2}$ & $\mathbf{0 , 0 0 0}$ & Valid \\
\hline Akuntabilitas Kinerja & $\mathbf{0 , 6 5 2 - \mathbf { 0 , 7 3 8 }}$ & $\mathbf{0 , 0 0 0}$ & Valid \\
\hline
\end{tabular}

\section{Sumber: Data Diolah Tahun 2014}

Berdasarkan Tabel 2. di atas dapat dilihat bahwa variabel Standar Akuntansi Pemerintahan, Sistem Pelaporan dan Akuntabilitas Kinerja semuanya valid. Dari semua variabel tersebut memiliki nilai signifikansi di bawah 0.01 yaitu bernilai 0.000 . Dengan demikian dapat disimpulkan bahwa semua pertanyaan dalam kuesioner mampu untuk mengukur variabel yang diharapkan.

\section{Uji Reliabilitas}

Uji Reliabilitas adalah pengujian untuk menguji konsistensi alat ukur, apakah hasilnya tetap konsisten jika pengukuran diulang. Untuk menguji reabilitas dalam penelitian ini menggunakan metode Cronbach Alpha. Metode pengambilan keputusan pada uji reabilitas dengan menggunakan batasan 0,7. Uji reliabilitas disajikan pada Tabel 3 berikut ini: 
Tabel 3. Hasil Uji Reliabilitas

\begin{tabular}{|l|l|l|l|}
\hline Variabel & Cronbach Alpha & Nilai Kritis & Keterangan \\
\hline Sistem Akuntansi Pemerintah & $\mathbf{0 , 9 1 4}$ & $\mathbf{0 , 7}$ & Reliabel \\
\hline Sistem Pelaporan & $\mathbf{0 , 8 5 8}$ & $\mathbf{0 , 7}$ & Reliabel \\
\hline Akuntabilitas Kinerja & $\mathbf{0 , 7 9 9}$ & $\mathbf{0 , 7}$ & Reliabel \\
\hline
\end{tabular}

\section{Sumber: Data Diolah Tahun 2014}

Berdasarkan tabel 3. di atas dapat dilihat bahwa Variabel Standar Akuntansi Pemerintah, Sistem Pelaporan dan Akuntabilitas Kinerja semuanya reliabel. Dari semua variabel tersebut memiliki nilai kritis lebih besar dari 0.7.

\section{Uji Asumsi Klasik}

\section{Pengujian Autokorelasi}

Uji autokorelasi bertujuan untuk menguji apakah suatu model regresi linier ada korelasi antara kesalahan pengganggu pada periode t-1 ( sebelumnya). Dalam penelitian ini uji autokorelasi yang digunakan adalah uji Durbin - Watson (DW test) yang hanya digunakan untuk autokorelasi tingkat satu (first order autocorrelation) dan mensyaratkan adanya intersep (konstanta) dan tidak ada variabel lag diantara variabel independen (Ghozali, 2006). Hasil pengujian autokorelasi untuk model regresi yang kedua disajikan pada Tabel 4. di bawah ini:

Tabel 4. Hasil Uji Autokorelasi

\begin{tabular}{|l|c|c|c|c|c|c|}
\hline $\begin{array}{c}\text { Durbin } \\
\text { Watson }\end{array}$ & $\mathrm{K}$ & $\mathrm{N}$ & $\mathrm{Dl}$ & $\mathrm{du}$ & kriteria & Keterangan \\
\hline 1,949 & 3 & 158 & 1,693 & 1,774 & $\mathrm{dl} \leq \mathrm{d} \geq \mathrm{du}$ & Tidak ada Autokorelasi \\
\hline
\end{tabular}

\section{Sumber: Data Diolah Tahun 2014}

Berdasarkan tabel kesimpulan dw test untuk observasi (n) sebanyak 158 variabel independen (k) sebanyak 3 variabel di peroleh nilai durbin upper (du) sebasar 1,774 dan durbin lower (dl) sebesar 1,693. Dengan menggunakan kriteria yang ditetapkan untuk menguji masalah autokorelasi diperoleh hasil $\mathrm{dl} \leq \mathrm{d} \geq \mathrm{du}$ sehingga disimpulkan tidak ada autokorelasi pada model regresi.

\section{Pengujian Multikolinearitas}

Uji multikolinieritas bertujuan untuk menguji apakah dalam model regresi ditemukan adanya korelasi yang tinggi atau sempurna antar variabel independen. Multikolinieritas dapat dilihat pada tolerance value atau Variance Inflation Factor (VIF). Apabila tolerance value dibawah 0,10 atau nilai VIF diatas 10 maka terjadi multikolinieritas. Apabila ternyata terdapat multikolinieritas, maka salah satu variabel harus dikeluarkan dari persamaan. Uji multikolinearitas dapat dilihat pada Tabel 5 . berikut ini: 


\section{Tabel 5. Uji Multikolinearitas}

\begin{tabular}{|c|c|c|c|}
\hline \multirow[b]{2}{*}{ Model } & \multicolumn{2}{|c|}{ Collinearity Statistics } & \multirow{2}{*}{ Keterangan } \\
\hline & Tolerance & VIF & \\
\hline Sistem_Akuntansi_Pemerintah & 0.808 & 1.238 & Bebas Mulitikolinearitas \\
\hline SISTEM_PELAPORAN & 0.808 & 1.238 & Bebas Mulitikolinearitas \\
\hline
\end{tabular}

\section{Sumber: Data Diolah Tahun 2014}

Hasil pengujian masalah multikolinieritas yang disajikan pada Tabel 5 . di atas menunjukan bahwa seluruh variabel independen yang digunakan bebas dari masalah multikolinieritas. Hasil tersebut dapat dilihat dari nilai Tolerance $>0,10$ dan nilai Variance Inflation Factor (VIP) $<10$.

\section{Pengujian Heterokedastisitas}

Uji heterokedatisitas digunakan untuk mengetahui ada atau tidaknya kesamaan varian dari residual untuk semua pengamatan pada model regresi. Untuk melihat ada atau tidak gejala heterokedastisitas, data akan diolah menggunakan metode Glejser. Gejala heterokedastisitas ditunjukkan oleh koefisien regresi dari masing-masing variabel bebas terhadap nilai absolute residualnya. Jika nilai signifikansinya lebih besar dari nilai alpha 0,05 , maka dapat dipastikan tidak mengandung gejala heterokedastisitas. Hasil perhitungan uji heterokedastisitas dapat dilihat pada tabel berikut ini:

Tabel 6. Hasil Uji Heterokedastisitas

\begin{tabular}{|c|c|c|c|c|c|c|}
\hline \multirow{2}{*}{\multicolumn{2}{|c|}{ Model }} & \multicolumn{2}{|c|}{$\begin{array}{l}\text { Unstandardized } \\
\text { Coefficients }\end{array}$} & \multirow{2}{*}{$\begin{array}{c}\begin{array}{c}\text { Standardized } \\
\text { Coefficients }\end{array} \\
\text { Beta }\end{array}$} & \multirow[b]{2}{*}{$\mathrm{t}$} & \multirow[b]{2}{*}{ Sig. } \\
\hline & & B & Std. Error & & & \\
\hline \multirow[t]{3}{*}{1} & (Constant) & 2.804 & 1.061 & & 2.641 & .009 \\
\hline & Sistem_Akuntansi_Pemerintah & -0.007 & 0.023 & -0.025 & -.283 & 0.778 \\
\hline & SISTEM_PELAPORAN & -0.047 & 0.045 & -0.095 & -1.060 & 0.291 \\
\hline
\end{tabular}

a. Dependent Variable: absres

Sumber: Data Diolah Tahun 2014

Dari hasil pengujian heteroskedasitas yang disajikan pada Tabel 6. di atas, untuk persamaan regresi terlihat bahwa semua variabel dalam penelitian ini bebas dari masalah heterokedastisitas, karena nilai signifikansinya lebih besar dari nilai alpha 0,05.

\section{Analisis Regresi Linier Berganda}

\section{Tabel 7. Analisis Linier Berganda}

\section{Coefficients ${ }^{\mathrm{a}}$}

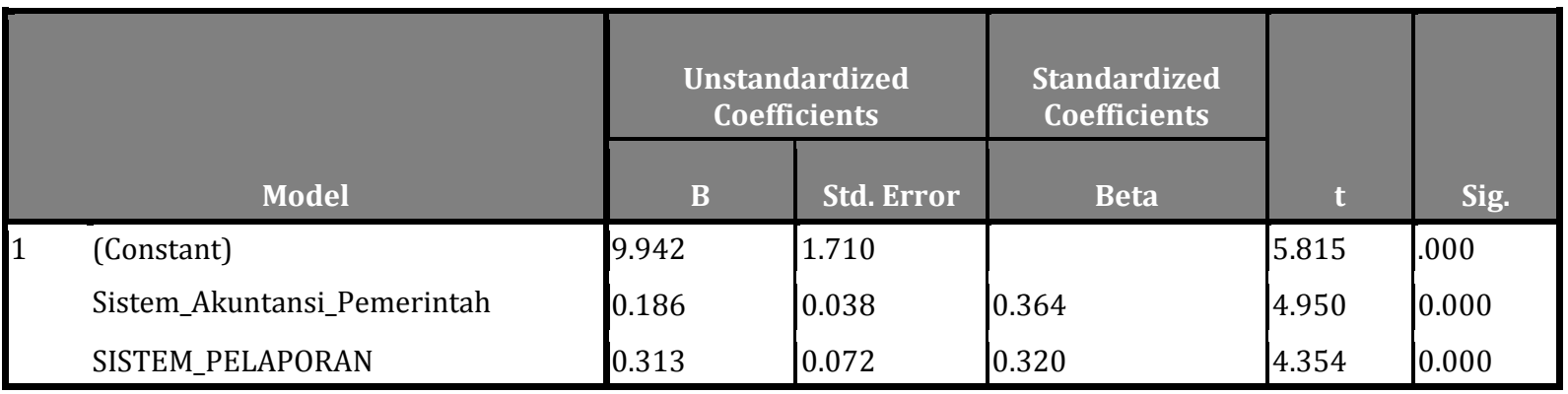

a. Dependent Variable: AKUNTABILITAS_KINERJA

Sumber: Data Diolah Tahun 2014 
berikut:

Berdasarkan Tabel 7. di atas maka persamaan regresi yang didapatkan adalah sebagai

$\mathrm{Y}=9,949+0,186 \mathrm{X}_{1}+0,313 \mathrm{X}_{2}$

Persamaan regresi linier berganda di atas dapat diartikan bahwa:

1. Nilai Konstanta sebesar 9,949 mempunyai makna bahwa nilai akuntabilitas kinerja (Y) sebesar 9,949, jika dipengaruhi oleh variabel variabel standar akuntansi pemerintah $\left(\mathrm{X}_{1}\right)$ dan sistem pelaporan $\left(\mathrm{X}_{2}\right)$ atau nilai $\mathrm{X}_{1}, \mathrm{X}_{2}=0$ atau konstan. Hal ini menunjukkan bahwa ada variabel lain yang mempengaruhi nilai akuntabilitas kinerja yang tidak dimasukkan dalam penelitian ini. Tanda positif bermakna bahwa akuntabilitas kinerja berada pada titik tertinggi jika dipengaruhi oleh variabel standar akuntansi pemerintah dan sistem pelaporan.

2. Koefisien regresi standar akuntansi pemerintah sebesar 0,186 menyatakan bahwa setiap peningkatan satu satuan standar akuntansi pemerintah maka akan meningkatkan standar akuntansi pemerintah sebesar 0,186 satuan.

3. Koefisien regresi sistem pelaporan sebesar 0,313 menyatakan bahwa setiap peningkatan satu satuan sistem pelaporan maka akan meningkatkan akuntabilitas kinerja sebesar 0,313 satuan.

\section{Uji t}

Selanjutnya untuk meyakinkan bahwa masing-masing variabel yaitu kejelasan sasaran anggaran, sistem akuntansi pemerintah dan sistem pelaporan terhadap akuntabilitas kinerja dilakukan pengujian secara parsial. Dari perhitungan SPSS yang disajikan dalam tabel 8 . diperoleh nilai t hitung sebagai berikut ini:

Tabel 8. Uji t

\begin{tabular}{|c|c|c|c|c|c|c|}
\hline \multirow{2}{*}{\multicolumn{2}{|c|}{ Model }} & \multicolumn{2}{|c|}{$\begin{array}{l}\text { Unstandardized } \\
\text { Coefficients }\end{array}$} & \multirow[b]{2}{*}{ thitung } & \multirow[b]{2}{*}{$\mathrm{t}$ tabel } & \multirow[b]{2}{*}{ Sig. } \\
\hline & & B & Std. Error & & & \\
\hline \multirow[t]{3}{*}{1} & (Constant) & 9.942 & 1.710 & 5.815 & & 0.000 \\
\hline & Sistem_Akuntansi_Pemerintah & 0.186 & 0.038 & 4.950 & 1,654 & 0.000 \\
\hline & SISTEM_PELAPORAN & 0.313 & 0.072 & 4.354 & 1,654 & 0.000 \\
\hline
\end{tabular}

a. Dependent Variable: AKUNTABILITAS_KINERJA

\section{Sumber : data diolah tahun 2014}

1. Variabel standar akuntansi pemerintah $\left(\mathrm{X}_{1}\right)$, menunjukkan $\mathrm{t}$ hitung sebesar 4,950 dan $\mathrm{t}$ tabel sebesar 1,654 pada tingkat signifikan 0,000, karena tingkat signifikan $0,000 \leq 0,05$ maka variabel standar akuntansi pemerintah berpengaruh dan signifikan terhadap variabel akuntabilitas kinerja. Dengan demikian hipotesis pertama diterima

2. Variabel sistem pelaporan $\left(\mathrm{X}_{2}\right)$, menunjukkan $\mathrm{t}$ hitung sebesar 4,354 dan $\mathrm{t}$ tabel sebesar 1,654 pada tingkat signifikan 0,002 , karena tingkat signifikan $0,000 \leq 0,05$ maka variabel sistem pelaporan berpengaruh dan signifikan terhadap variabel akuntabilitas kinerja. Dengan demikian hipotesis kedua diterima

\section{Uji F}

Uji F seringkali juga dinamakan dengan analysis of variance. Pengujian ini dimaksudkan untuk mengetahui apakah semusa variabel independen atau bebas yang dimasukkan dalam model mempenyai pengaruh secara bersama-sama terhadap variabel dependen atau terikat. Variabel-variabel penjelas yang digunakan dalam model, secara bersama-sama mempunyai pengaruh atau tidak terhadap variabel yang ingin dijelaskan dengan menggunakan uji $\mathrm{F}$ test. Pengujian ini dilakukan untuk menguji pengaruh X terhadap Y secara bersama-sama. Untuk lebih jelasnya dapat dilihat pada Tabel 4.9 di bawah ini: 
Tabel 9. Uji F

\begin{tabular}{|c|c|c|c|c|c|c|}
\hline & Model & Sum of Squares & df & Mean Square & $\mathrm{F}$ & Sig. \\
\hline \multirow[t]{3}{*}{1} & Regression & 299.741 & 2 & 149.871 & 38.584 & $0.000^{a}$ \\
\hline & Residual & 590.414 & 152 & 3.884 & & \\
\hline & Total & 890.155 & 154 & & & \\
\hline
\end{tabular}

a. Predictors: (Constant), SISTEM_PELAPORAN, Sistem_Akuntansi_Pemerintah

b. Dependent Variable: AKUNTABILITAS_KINERJA

\section{Sumber: Data Diolah tahun 2014}

Berdasarkan Tabel 9. tampak bahwa nilai $\mathrm{F}$ hitung sebesar 38,584 lebih besar dari $\mathrm{F}$ tabel sebesar 2,70 dengan angka signifikansi $=0,000<\alpha=0,05$. Hal ini berarti bahwa model penelitian adalah baik atau dengan kata lain ada pengaruh yang signifikan antara standar akuntansi pemerintah dan sistem pelaporan terhadap akuntabilitas kinerja.

\section{Pembahasan}

\section{Pengaruh Standar Akuntansi Pemerintah $\left(\mathrm{X}_{1}\right)$ Terhadap Akuntabilitas Kinerja Instansi Pemerintah Kota Bengkulu}

Berdasarkan hasil regresi linier pada penelitian ini, hasil pengujian hipotesis kedua secara parsial diperoleh menunjukkan t hitung sebesar 4,950 dan t tabel sebesar 1,654 pada tingkat signifikan 0,000, karena tingkat signifikan $0,000 \leq 0.05$ maka variabel Standar Akuntansi Pemerintah berpengaruh dan signifikan terhadap variabel akuntabilitas kinerja. Ini mendukung hasil penelitian Dian Tri Hapsari (2014) yang menjelaskan bahwa Standar Akuntansi Pemerintahan berpengaruh signifikan terhadap Akuntabilitas Kineja Isntansi Pemerintah Kota Lumajang.

Dengan diterimanya hipotesis kedua dalam penelitian maka dapat diartikan bahwa dalam menyajikan laporan keuangan pemerintah telah sesuai dengan SAP, sehingga akan meningkatkan Akuntabilitas Kinerja instansi Pemerintah Kota Bengkulu.

\section{Pengaruh Sistem Pelaporan $\left(\mathrm{X}_{2}\right)$ terhadap Akuntabilitas Kinerja Instansi Pemerintah Daerah Kota Bengkulu (Y)}

Berdasarkan hasil regresi linier pada penelitian ini, hasil pengujian hipotesis kedua secara parsial diperoleh menunjukkan t hitung sebesar 4,354 dan t tabel sebesar 1,654 pada tingkat signifikan 0,000, karena tingkat signifikan 0,002 $\leq 0.05$ maka variabel Sistem Pelaporan berpengaruh dan signifikan terhadap variabel akuntabilitas kinerja. Hasil ini menunjukkan bahwa asumsi yang menjelaskan bahwa semakin tinggi tingkat sistem pelaporan berpengaruh terhadap semakin tingginya tingkat akuntabilitas kinerja instansi pemerintah.

Pelaporan kinerja ini dimaksudkan untuk mengkomunikasikan capaian kinerja instansi pemerintah dalam suatu tahun anggaran yang dikaitkan dengan proses pencapaian tujuan dan sasasaran instansi pemerintah.

\section{Pengaruh Standar Akuntansi Pemerintahan $\left(\mathrm{X}_{1}\right)$ dan Sistem Pelaporan $\left(\mathrm{X}_{2}\right)$ Terhadap Akuntabilitas Kinerja Instansi Pemerintah Daerah Kota Bengkulu (Y)}

Pada Pengujian secara simultan diperoleh hasil bahwa nilai $\mathrm{F}$ hitung sebesar 38,854 lebih besar dari $\mathrm{F}$ tabel sebesar 25,495 dengan angka signifikansi $=0,000<\alpha=0,05$. Hal ini berarti bahwa model penelitian adalah fit atau dengan kata lain ada pengaruh yang signifikan 
antara Standar Akuntansi Pemerintah dan Sistem Pelaporan terhadap Akuntabilitas Kinerja Instansi Pemerintah Daerah Kota Bengkulu .

Maka dapat ditarik kesimpulan bahwa standar akuntansi Pemerintah dan sistem pelaporan di Kota Bengkulu telah berjalan dengan baik, sehingga Akuntabilitas Kinerja Instansi pemerintah Kota Bengkulu dapat beroperasi secara efisien, efektif, transparansi, dan responsif terhadap aspirasi masyarakat dan lingkungan di Kota Bengkulu.

\section{KESIMPULAN DAN SARAN}

\section{Kesimpulan}

1. Standar akuntansi pemerintah berpengaruh dan signifikan terhadap akuntabilitas kinerja, hal ini ditunjukkan dengan nilai koefisien $\beta$ sebesar 0,186 pada tingkat signifikan 0,000, karena tingkat signifikan $0.000 \leq 0.05$. Dengan diterima hipotesis ini berarti semakin tinggi standar akuntansi pemerintah yang diterapkan oleh Instansi Pemerintah maka akan meningkatkan akuntabilitas kinerja

2. Sistem pelaporan berpengaruh dan signifikan terhadap akuntabilitas kinerja, hal ini ditunjukkan dengan nilai koefisien $\beta$ sebesar 0,313 pada tingkat signifikan 0,000, karena tingkat signifikan $0,000 \leq 0.05$ maka variabel sistem pelaporan berpengaruh dan signifikan terhadap variabel akuntabilitas kinerja. Dengan diterima hipotesis ini berarti semakin tinggi sistem pelaporan yang dimiliki oleh Instansi Pemerintah maka akan meningkatkan akuntabilitas kinerja

3. Kejelasan sasaran anggaran, standar akuntansi pemerintah dan sistem pelaporan berpengaruh dan signfikan terhadap akuntabilitas kinerja ditunjukkan dengan nilai $F$ hitung sebesar 26,227 dengan angka signifikansi $=0.000<\alpha=0.05$. Hal ini berarti bahwa ada pengaruh yang signifikan antara Kejelasan sasaran anggaran, standar akuntansi pemerintah dan sistem pelaporan berpengaruh dan signfikan terhadap akuntabilitas kinerja

\section{Saran}

1. Untuk lebih mempertahankan dan meningkatkan pengetahuan pegawai dan pejabatpejabat di Lingkungan pemeritah Daerah Bengkulu tentang penyusunan laporan sesuai dengan Standar akuntansi pemerintah melalui pelatihan-pelatihan dan seminar-seminar, sehingga dapat menyusun dan memahami laporan sesuai dengan standar akuntansi pemerintah dan mewujudkan transparansi dan akuntanbilitas kinerja di lingkungan pemerintah Daerah Bengkulu.

2. Untuk penyelenggara permeritah agar lebih mempertahankan dan meningkatkan penggunaan sistem pelaporan agar hasilnya dapat menjadi acuan bagi pemakai untuk dijadikan bahan dalam rangka pengambilan keputusan.

3. Hasil penelitian diharapkan dapat memotivasi peneliti selanjutnya terutama yang berkaitan dengan akuntabilitas kinerja instansi pemerintah. Untuk penelitian selanjutnya diharapkan dapat mengembangkan variabel lain, seperti peraturan pemerintah, pengendalian akuntansi, good governance yang juga mempengaruhi akuntabilitas kinerja instansi pemerintah Daerah Bengkulu.

\section{DAFTAR PUSTAKA}

Abdul Halim,2004. Akuntansi Sektor Publik : Akuntansi Keuangan Daerah", Jakarta: Salemba Empat.

Anthony. R.N.,J. Dearden,N.M. Bedford, 1999. Sistem Pengendalian Manajemen, Edisi 6. Jakarta: Erlangga. 
Dian Tri Hapsari. 2014. Pengaruh penerapan standar akuntansi pemerintahan, Ketaatan pada peraturan perundangan, kompetensi Aparatur pemerintah daerah dan motivasi kerja Terhadap akuntabilitas kinerja instansi pemerintah(studi empiris pada pemerintah kabupaten lumajang). Universitas Jember, Jember.

Duwi Prayitno. 2010 . Tehnik Muda dan Cepat Melakukan Analisis Data Penelitian. Gava Media Yogyakarta.

Ghozali.2005. Analisis Multivariat. Penerbit Universitas Diponegoro.Semarang

Http://bengkulu.bpk.go.id. Bengkulu Utara dan lebong memperoleh WTP. Tanggal 25 Bulan Juni 2013.

http://bengkuluekspress.com/4-kabupaten-raih-wtp/. 4 PEMDA WTP 4 PEMDA WDP. Tanggal 13 bulan juni 2014.

Indra Bastian. 2010. Akuntansi Sektor Publik. Jakarta: Penerbit Erlangga.

Keputusan Kepala Lembaga Administrasi Negara Nomor 239/IX/6/2003 tentang Perbaikan Pedoman Penyusunan Laporan Akuntabilitas Kinerja Instansi Pemerintah.

LAN, BPKP. 2000. Pengukuran Kinerja Instansi Pemerintah, Modul Sosialisasi Sistem Akuntabilitas Kinerja Instansi Pemerintah (AKIP). Lembaga Administrasi Negara, Jakarta.

Mardiasmo. 2002b. Akuntansi Sektor Publik. Edisi Pertama. Penerbit Andi Yogyakarta, Yogyakarta.

Moh. Mahsun, dkk. 2006. Penelitian Bisnis. Penerbit: Andi Yogyakarta, Yoyakarta.

Nur Indriantoro dan Bambang Supomo. 2002. Metodologi Penelitian Bisnis Untuk Akuntansi dan Manajemen, Edisi Pertama. Yogyakarta : BPFE Yogyakarta.

Pusat Pendidikan dan Pelatihan BPKP .2003. Modul Akuntabilitas Instansi Pemerintah. Jakarta: Badan Pengawasan Keuangan dan Pembangunan. , Undang - Undang RI No. 17 Tahun 2003. tentang Keuangan Negara. Pemerintahan.

Sugiyono, 2004. Metode Penelitian Bisnis. Penerbit: Alfabet, Bandung. 